\title{
Determinants of Working Capital Requirement on Manufacturing Firms
}

\author{
Damot Alehegne ${ }^{1, *}$, Endalachew Bekalu², Abatneh Mengist ${ }^{3}$ \\ ${ }^{1}$ Department of Accounting and Finance, Raya University, Michew, Ethiopia \\ ${ }^{2}$ Department of Accounting and Finance, Mekdela Amba Univrsity, Mekdela, Ethiopia \\ ${ }^{3}$ Department of Accounting and Finance, Jinka University, Jinka, Ethiopia \\ Email address: \\ damotalehegne5@gmail.com (D. Alehegne), endalachewbekalu@gmail.com (E. Bekalu), abatnehmengist@gmail.com (A. Mengist) \\ ${ }^{*}$ Corresponding author
}

\section{To cite this article:}

Damot Alehegne, Endalachew Bekalu, Abatneh Mengist. Determinants of Working Capital Requirement on Manufacturing Firms. European Business \& Management. Vol. 5, No. 1, 2019, pp. 1-6. doi: 10.11648/j.ebm.20190501.11

Received: April 3, 2019; Accepted: May 21, 2019; Published: June 5, 2019

\begin{abstract}
Working capital investments are essential for daily business operations of an entity. For that matter firms make huge amounts of investments in working capital that enables them to pay recurring obligations. The main aim of this study is to investigate the determinants of working capital requirement of 35 large taxpayer manufacturing firms from food and beverage industry of Addis Ababa by employing explanatory research design with quantitative approach. Firms' financial statements were collected for five years period from 2011 to 2015. Cash conversion cycle, return on asset, operating cash flow, leverage, firm size, growth rate, real GDP growth rate and inflation rate were used as an explanatory variables to measure the size or level of working capital requirement, and net working capital deflated by total asset were used as a dependent variable. Data was analyzed with the help of STATA (version 13) and, descriptive and correlation analysis and pooled panel data regression models of cross-sectional and time series data were employed. Results from the analysis revealed that there is statistically significant negative relationship between working capital requirement with leverage, firm size, real GDP growth rate and inflation rate. And there is positive and significant relationship between working capital requirements with cash conversion cycle.
\end{abstract}

Keywords: Working Capital Requirement, Manufacturing Firms, Food and Beverage, Addis Ababa

\section{Introduction}

The corporate finance literature has traditionally focused on the study of long-term financial decisions, particularly investments, capital structure, dividends or company valuation decisions. However, short-term assets and liabilities are important components of total assets and need to be carefully analyzed. Management of these short-term assets and liabilities warrants a careful investigation, since the working capital management plays an important role in a firm's profitability and risk as well as its value. [1] Firms try to maintain an optimum level of working capital that maximizes the value [2, 3]. In practice, working capital management has become one of the most important issues in organizations, where many financial managers are finding it difficult to identify the important drivers of working capital and the optimum level of working capital [4]. Consequently, companies can minimize risk and improve their overall performance if they can understand the role and determinants of working capital requirement.

Though the degree of working capital requirement varies across firms because of several factors such as nature of business, scale of operation, production cycle, business cycle, seasonality and production policy, credit policy, growth and expansion opportunities, operating efficiency and availability of raw materials, it is hardly found that a company survives without working capital. Just as human body cannot function without blood, business too will not function as a business unless some resources are reserved as working capital in order to meet requirements of daily business operations. But from economics point of view those resources are scarce, nothing is freely available. Thus management of those 
resources has its own value for any business striving to generate more from this world of scarcity.

Determining the important factors affecting working capital requirement, would help managers to determine the optimal level of investment in current assets as well as the appropriate sources to finance them. In addition, they would be well prepared and ready for unpredicted situations that have unexpected effects on firms performance.

The main objective of working capital management is to maintain an optimal balance among each of the working capital components. Business success heavily depends on the ability of the financial managers to effectively manage receivables, inventory, and payables [5]. An optimal level of working capital is the one in which a balance is achieved between risk and efficiency. It requires continuous monitoring to maintain the optimum level of various components of working capital, such as cash, receivables, inventory and payables.

\section{Statement of the Problem}

Working capital management is an important component of corporate finance because of its direct impact on profitability and liquidity of a business entity [6]. Owning to this strategic role of the firms value creation process and the following recent global financial crisis efficient management of working capital requirement is not a question of pleasure, rather it becomes a question of survival [7]. Numerous research studies addressing the determinants of working capital requirement have begin to appear in the corporate finance literature. However, a study contended that the findings are quite mixed. They lack cohesiveness which is attributable to variations in factors such as culture, perceptions, market size, industry variations, market depth, efficiency, and regulations, Enow \& Brijlal. [8]

There is no actual standard or rule of thumb on the amount of working capital needs for the day to day operations of the firm. It depends on many factors such as nature and size of business, production policy, growth and expansion, supply and demand of market, sales volume, management ability, external environment, price level change, and working capital management policy. [9] In order to make optimal decision on working capital management a firm should maintains appropriate amount of working capital component by considering the balance between profitability and liquidity of the firm. Profitability position should not be at the expense of the liquidity position, and liquidity should not be at the expense of profitability because both have their own importance for long lasting success of firm. Therefore, the level of working capital should balance between profitability and liquidity [6]. Most studies on the determinants of working capital requirement in developing and emerging countries as found in the extant literature examined the relationship between determinant factos and the size of net working capital. Factors that determine the working capital requirement are often not explored. And the present study wants to fill the gap on lack of clarity about the determinant factors of working capital requirement especially in developing economy like Ethiopia and this is a motivating factor for this study.

Even though several studies about the determinants of working capital requirement has been undertaken, in most developed countries; As it stands to most of developing nations, various researches were conducted on the impact of working capital management on profitability and firm performance in Ethiopian context such as (Tewodros, 2010, Ephrem, 2011. Tirngo, 2013; Wobshet, 2014; Mifta, 2016; Abenet \& Venkateswarlu, 2016; Arega et al., 2016). But to the best of the researchers knowledge it appears there has not been any study conducted on the determinants of working capital requirement in Ethiopian context and this study wants to fill the gap noticed above by having an intention to test how and to what extent different financial and economic factors determine the level or size of net working capital of Ethiopian manufacturing companies with a special emphasis on food and beverage manufacturing firms in Addis Ababa. Finally this study wants to add body of literature to the existing stock of knowledge on the factors that determine working capital requirement.

\section{Objective of the Study}

The main objective of this study is to find the important factors that determine the size of working capital requirement in selected food and beverage manufacturing firms in Addis Ababa.

\section{Significance of the Study}

The theoretical contribution of this study is that it can provide additional insights to the existing Stock of knowledge on the determinants of working capital requirement by providing empirical evidence from underexplored business environment, the Ethiopian manufacturing industries. To the practical business undertakings, the findings of this study can provide an understanding on the relationship between working capital requirement and its determinants. As a result it would assist managers of the manufacturing companies to improve performance of their businesses by setting the required level of working capital. Additionally, this research can have implications to policy makers by studying financial and economic matters affecting working capital requirement of the manufacturing industries that can be used as an additional information to design policies and regulations to the sector.

\section{Empirical Literatures}

Suleiman, M. \& Rasha, T have conducted a study on the determinants of working capital requirement in Palestinian industrial corporation by taking a sample of 11 industrial firms that are listed on the Palestine Securities Exchange for eight years' time period that ranges from (2004-2011) and the study found that the cash conversion cycle, return on assets 
and operating cash flow are a significant determinant factors and positively related to the working capital requirements, while leverage and firm size are significant but negatively related to the working capital requirements. [10] A study by Azeem, M and Marsap, A. investigated on determinant factors and working capital requirement of Pakistani nonfinancial firms by taking into account different economic and financial variables relating to the business over a period of six years (2004-2009). Pooled Ordinary Least Square (OLS) regression models were used to estimate the determinants of working capital requirement. The study found that operating cycle, return on assets, leverage, size and level of economic activity is negatively related to working capital requirements of a firm where as operating cash flows and sales growth are positively related to working capital requirements. [11] A study of Nazir, M \& Afza, T Working capital requirement and the determining factors in Pakistan by employing a study of 132 manufacturing firms from 14 industrial groups that were listed on Karachi Stock Exchange (KSE) between the periods 2004-2007 was undertaken. The pooled panel regression model result found that Leverage of a firm is strongly and negatively related to the working capital management of a firm, indicating that with a rising debt to total assets ratio, the firms are supposed to pay more attention to efficient management of working capital to avoid much more capital being tied up in account receivables and inventories. [12] A study of Adekunle investigated on the determinants of working capital requirement of Nigerian firms and the study examine the determinants of working capital requirements of thirty non-financial firms listed on the Nigerian Stock Exchange between 2004 and 2011. Panel data methodology were employed and Ordinary Least Squares (OLS) used as estimation technique. Regression results reveal that five explanatory variables- firm's leverage, size, industry classification, return on asset and operating cycle are significant factors that determine the firms' working capital requirements for the period under study. [13] Guizani, M have conducted a research on the financial determinants of corporate cash holding of an oil rich country: Evidenced from Kingdom of Saudi Arabia. The study was investigated for the sample of Saudi firms over a period of 2006- 2014, and the collected data were analyzed by using static and dynamic panel regression model. In this study corporate cash holding were used as dependent variable and several financial factors such as leverage, dividend payment, profitability, growth opportunity, capital expenditure, firm size, cash flow volatility, net working capital and oil price were considered as independent variables. The results of the study show that leverage, firm size, capital expenditure, net working capital and cash flow volatility are the main determinants of cash holdings of Saudi firms and profitability, dividend payment, growth opportunity, and oil price were not significant factors for the determination of the corporate cash holding of Sadi Arabian selected firms [14].

\section{Research Methodology}

In order to achieve the objective of this research, the study adapts explanatory research design. The required data to analyze the determinants of working capital requirement was quantitative in nature, accounting figures extracted from audited annual financial statements (basically the balance sheet and income statement) prepared by the sample companies for the past five most recent consecutive years covering from 2011 to 2015 . The data required for this study were solely obtained from secondary sources (financial statements) and was collected through document review. The data for this study (the financial statements) was collected from authoritative governmental agency of Ethiopian Revenue and Customs Authority (ERCA), large taxpayers ${ }^{\text {ee }}$ branch in Addis Ababa. Descripive and statistical analysis were employed for this study purpose. The study has used panel data for the period 2011-2015 and an OLS regression model to estimate the determinants of working capital requirement.

\section{Model Specification}

The following model was developed based on previous literatures and the model of the study is as follows:

$$
\text { NWC_TA }=\alpha+\beta 1 C C C t_{i}+\beta 2 \text { OCF-TA }_{i}+\beta 3 \text { LN FS } t_{i}+\beta 4 \text { LEV t }_{i}+\beta 5 \text { ROA }_{i}+\beta 6 \text { GR }_{i}+\beta 7 \text { RGDPGR } t+\beta 8 \text { IR }_{t}+€
$$

Where; NWC-TA is net working capital deflated by total asset. $\alpha$ is constant term of the model, CCC is cash conversion cycle, OCF-TA is operating cash flow deflated by total asset, LN FS is Natural log of total assets as proxy for the size of firm, Lev is Leverage as measured by debt to total assets ratio of firm, ROA is Return on assets for firm, GR is Growth of the firm, RGDPGR is the real gross domestic product growth rate,

\section{Data Analysis}

\subsection{Descriptive Statistics}

The following table indicates the determinants of working capital requirement on manufacturing firms in Ethiopia. INR is inflation rate and $€$ is the error term.

Table 1. descriptive statistics of all variables.

\begin{tabular}{|c|c|c|c|c|c|}
\hline Variable & Observation & Mean & Standard Deviation & Minimum & Maximum \\
\hline NWC-TA & 175 & 0.2574349 & 0.4220049 & -0.8518 & 0.9879 \\
\hline $\mathrm{CCC}$ & 175 & 151.1042 & 172.2579 & -747.0196 & 943.6585 \\
\hline ROA & 175 & 0.1132531 & 0.2504263 & -0.7095 & 0.9985 \\
\hline
\end{tabular}




\begin{tabular}{llllll}
\hline Variable & Observation & Mean & Standard Deviation & Minimum & Maximum \\
\hline LEV & 175 & 0.4073503 & 0.2306466 & 0.0021 & 0.9956 \\
LNFS & 175 & 7.933429 & 0.6324003 & 6.5433 & 9.8922 \\
GR & 175 & 0.1891977 & 0.3106931 & -0.223 & 2.3676 \\
RGDPGR & 175 & 0.1014 & 0.0087566 & 0.087 & 0.114 \\
INR & 175 & 0.163 & 0.0971407 & 0.077 & 0.341 \\
\hline
\end{tabular}

Source: Financial statements of sample firms (Stata output).

Regarding to the independent variables a descriptive summary statistics of Net working capital ratios. Of the determinants of net working capital ratios, one is the cash conversion cycle, a proxy variable to measure the number of days needed to convert its purchases from raw materials to finished product and sale it for cash. On this table, the mean value for cash conversion cycle (CCC) is 151 days with a standard deviation of 172 days. This shows that firms in the sample will take around 151 days period, on average, to convert their inventories into sales, collect cash from their credit sales and finally to make cash payment for their credit purchases, and it deviates by around 172 days to both sides of the mean distribution. In addition to, a minimum value of cash conversion cycle of -747 days was observed implying that some firms in the sample will take longer period of time to pay for their creditors than the days they take to sell their inventory and collect cash from their credit sell. The maximum value is about 944 days and it shows that firms in the sample wait up to 944 days to make cash inflows from sale of inventories even after they made payments for creditors. Another measure of net working capital is return on asset one of the most widely used measure of financial performance of a firm, as it shown from the above table the mean value of return on asset (ROA ) is 11 percent with a standard deviations of 25 percent. The minimum values of return on asset is -70.95 percent. Those figures shows that, profitability of the sample firms as measured by return on asset, was about 11 percent on average throughout the five years study period covering from 2011 to 2015 and it deviates from the mean value to both sides by 25 percent.

\subsection{Correlation Analysis}

Correlation analysis was conducted in this section in order to analyze and examine the relationship between net working capital and its determinant factors.

Table 2. Correlation matrix between variables.

\begin{tabular}{lllllll}
\hline NWC-TA & CCC & ROA & OCF-TA & LEV & LNFS & GR \\
\hline 1.000 & & & & & \\
0.1979 & 1.000 & & & & \\
0.3056 & 0.1211 & 1.000 & & & \\
0.0865 & -0.006 & 0.1696 & 1.000 & & \\
0.0019 & 0.0532 & 0.0417 & 0.0373 & 1.000 & & \\
-0.5197 & 0.1422 & -0.205 & 0.0666 & -0.085 & 1.000 & 1.000 \\
-0.0246 & 0.0990 & -0.027 & -0.001 & 0.1419 & -0.023 & -0.257 \\
-0.082 & -0.098 & 0.0220 & -0.078 & 0.0006 & -0.023 & 1.000 \\
-0.028 & 0.0060 & -0.064 & 0.0819 & -0.084 & 0.0420 & 0.0269 \\
\hline
\end{tabular}

Source: Financial statements of sample firm (STATA output).

As shown from the correlation table, there is a positive correlation coefficient between NWC -TA and CCC of 0.1979. This implies that the longer the cash conversion cycle, the greater the net investment in current asset.

Net working capital and return on asset has a positive correlation coefficient of 0.3056 which indicates the more the firm is profitable, the greater the cash to invest in investment activities.

In similar fashion, the correlation coefficient between net working capital and operating cash flow is 0.0865 . This positive relationship implies that the higher the operating cash flow, the larger would be the amount to be invested in working capital items and vice versa.

\subsection{Regression Analysis}

Table 3. Regression result.

\begin{tabular}{llllll}
\hline NWC-TA & Coefficient & Robust Std, Err & T & P $>$ [ t ] & (95\% Conf, interval) \\
\hline CCC & 0.0001876 & 0.0001031 & 1.82 & 0.078 & $-0.0000219-0.0003971$ \\
ROA & 0.0965012 & 0.1130066 & 0.85 & 0.399 & $-0.1331559-0.3261584$ \\
OCF-TA & -0.0472753 & 0.0641289 & -0.74 & 0.466 & $-0.1776009-0.0830503$ \\
LEV & -0.0371220 & 0.1297967 & -2.86 & 0.007 & $-0.634999,-0.1074416$ \\
LNFS & -0.2530517 & 0.0504744 & -5.01 & 0.000 & $-0.3556281,-0.1504754$ \\
GR & -0.0797755 & 0.0651864 & -1.22 & 0.229 & $-0.2122502-0.0526992$ \\
RGDPGR & -9.14444 & 3.071388 & -2.98 & 0.005 & $-15.38625,-2.92628$ \\
INR & -0.6069733 & 0.278664 & -2.18 & 0.036 & $-1.173287,-0.04066$ \\
Cons & 3.417554 & 0.4605239 & 7.42 & 0.000 & $2.481657,4.353451$ \\
sigma-u & 0.3012284 & & & & \\
\hline
\end{tabular}




\begin{tabular}{llllll}
\hline NWC-TA & Coefficient & Robust Std, Err & T & P $>[\mathbf{t}]$ & (95\% Conf, interval) \\
\hline Sigma-e & 0.22363231 & & & & \\
Rho & 0.64467904 & & & \\
\hline
\end{tabular}

$\mathrm{Obs}=175$.

R-sq $=0.3059$.

$\mathrm{F}(8,34)=6.72$.

The fixed effect regression results revealed that the coefficient of CCC is 0.0001876 and with a p-value of 0.078 which is statistically significant at $10 \%$ significance level. This positive and significant relationship between cash conversion cycle and net working capital is coming from because of the longer the cash conversion cycle, the greater the net investment in current asset, and hence the greater the need for financing of current asset and the results of this study is contrary to the findings of Narender et al. (2009), but consistent with Lamberson (1995), Chiou and Cheng (2006), Nazir and Afza (2009) [12] and Ranjith (2008) The regression result that are shown in the above table indicate that the regression coefficient of leverage is $(-0.3712)$ which is statistically highly significant at $1 \%$ of level of significant with a p- value of 0.007 Leverage of a firm is strongly and negatively related to the working capital requirements of a firm, indicating that with a rising debt to total assets ratio, the firms are supposed to pay more attention to efficient management of working capital to avoid much capital being tied up in account receivables and inventories. So, companies with an increasing debt to total assets ratio (high leverage) show lower working capital requirements. That is in accordance with the Pecking Order theory.

In the above fixed effect regression result the regression coefficient of firm size is $(-0.2530517)$ which is statistically highly significant at $1 \%$ level of significant with a p- value of 0.000 The negative relationship between firm size and working capital requirement implies that larger firms have shorter cash conversion cycle. Moss and Stine (1993) asserted that the better access of larger firms to money market make able those to afford and keep a lower amount of current assets, since larger firms can finance their short- term needs through borrowing as quickly as possible. Moreover, Niskanen \& Niskanen [15] did argue that larger firms have stronger bargaining power with credit suppliers, and would use these advantages to finance their working capital. According to the above fixed effect regression result the coefficient of real GDP growth rate is $(-9.14444)$ which is statistically significant with a p- value of 0.005 . This negative and statistically significant relationship between economic condition as measured by real GDP growth rate and net working capital investment is found to be highly significant in affecting working capital investment. Abundance of funds during economic boom periods will not be a cause for worry and firms will thus not be too concerned about their level of working capital, but during recession periods, as much money as possible needs to be squeezed out and the easiest way is through working capital improvements.

\section{Conclusion}

Multiple regression analysis of the model framework developed to examine the determinants of working capital requirement after diagnostic tests of OLS assumptions. The statistical regression results of the model have shown that cash conversion cycle is positively related with net working capital is due to the fact that the longer the cash conversion cycle, the greater the net investment in current asset. The regression analysis of leverage has shown that there is strong and negative relationship with net working capital requirement. The regression analysis of firm size revealed that there is strong and negative relationship with net working capital requirement. The larger the firm the less working capital to total assets is required and additionally large firms have shorter cash conversion cycle and they have better access to money market to finance their short term needs. Moreover, most of the time larger firms may reach at the stage of operating efficiency and the firm may utilize their own short term asset at its optimal level and at this time the firm may require additional amount of current asset to support the long term investment of the firm The regression results of real GDP growth rate indicate that there is strong and negative relationship with net working capital required for the selected food and beverage manufacturing firms. Moreover, when the economic condition is good enough for the growth and expansion of the firm and the condition will lead the firm to make profit and higher portion of the profit will be retained for the purpose of further expansion of the firm investment, but the firm will not require additional amount of cash other than internal financing. Finally, inflation rate has a strong and negative relationship with net working capital requirement. This indicate that higher level of inflation rate must be compensated by higher level of expected return and this fact will inclined the firm to have much more long term investment in an expense of short term investment.

\section{Recommendation}

This study has revealed a close association between net working capital requirement and different firm specific and macro-economic factors in manufacturing industries of Ethiopia. Thus, managers or/and owners of those industries should pay due attention to their working capital investments. In general, based on the empirical results of this study, the researcher forwards the following recommendations to the food and beverage manufacturing industries of Addis Ababa.

Cash conversion cycle has a positive and significant relationship with the level of working capital required for the 
firm. Thus the financial managers of that firm should have to pay more attention to shorten the cash conversion cycle by accelerating cash collection period and lengthen the payment period and this would give an opportunity to minimize the working capital required for daily operation and this might cause the shift in firms investment in to other profitable long term investment other than investing in short term asset.

Leverage has strong negative relationship with net working capital requirement for the selected food and beverage manufacturing firms in Addis Ababa. Thus financial managers of those firms should have to pay more attention to efficient management of working capital to avoid much capital being tied up in unprofitable items like accounts receivables and inventories.

Firm size has strong negative relationship with net working capital requirement of the firm. Thus financial managers and owners of large firms should have to give due consideration for the bargaining power with credit suppliers and maintain good relationship with suppliers and this would give an advantage to finance their working capital required for the daily operation and this could give the chance to divert the working capital finance to the other profitable long term investment.

Real GDP growth rate is found to be strong negative relationship with net working capital requirement for selected food and beverage manufacturing firms in Addis Ababa. Thus in the times of economic expansion the financial managers of those firms should have to pay more attention on long term investment by minimizing investing on short term asset in order to be the best beneficiary from the advantages of economic expansion.

\section{References}

[1] Smith, A. J., 1980, Corporate Ownership Structure and Performance: The Case of Management Buyouts, Journal of Financial Economics, v27, 143-164.

[2] Deloof, M. (2003). Does working capital management affect profitability of Belgian firms.

[3] Afza T and MS Nazir (2007), Economic competitiveness and human resource development; Am FDI perspective, Pakistan economic and social review PP 167-80, Vol; 45.
[4] Lamberson, M. (1995). Changes in Working Capital of Small Firms in Relation to Changes in Economic Activity. MidAmerican Journal of Business, 10 (2), 45-50. http://dx.doi.org/10.1108/19355181199500015.

[5] Filbeck and Krueger, (2005), An analysis of working capital management results across industries.

[6] Raheman, A., \& Nasr, M. (2007). Working capital management and profitability - case of Pakistani firms. International review of business research papers, 3 (1), 279 300 .

[7] Charitou, M. S., Elfani, M., \& Lois, P. (2010). The Effect of Working Capital Management on Firm's Profitability: Empirical Evidence From An Emerging Market. Journal Of Business \& Economics Research, 8 (12), 63-68.

[8] Enow \& Brijlal (2014), The use of financial management practice by small, medium and micro enterprise; A perspective from South Africa.

[9] Brigham, E. F., \& Houston, J. F. (2009). Fundamentals of financial management (12th ed) Pearson, USA: South-Western Cengage Learning.

[10] Suleiman, M, Rash, T. (2012). The determinants of working capital requirements in Palestine industrial corporation, International Journal of Economics and Finance; Vol. 5, No. 1; 2013.

[11] [Azeem, M, \& Marsap, A. (2015). Determinants factors and working capital requirement, International Journal of Economics and Finance.

[12] Nazir, S, \& Afza, T. (2009). Working capital requirements and the determing factors in Pakistan.

[13] Adekunle, O. (2015). What are the determinants of working capital requirement of Nigerian firms, Research Journal of Finance and Accounting Vol. 6, No. 6, 2015.

[14] Guzani, M, (2017). Financial determinants of corporate cash holding in an oil rich country: Evidenced from kingdom of Saudi Arabia.

[15] Niskanen, J., \& Niskanen, M. (2006). The Determinants of Corporate Trade Credit Polices in a Bank Dominated Financial Environment: The Case of Finnish Small Firms. European Financial Management. 